\title{
The Effective of Using Worksheet with the Problem- Based Learning (PBL) Through Google Classrooms to Improve Critical Thinking Skills During the Covid-19 Pandemic
}

\author{
Sony Yunior Erlangga ${ }^{1, *}$ Jumadi $^{2,}$ Nuraini Nadhiroh ${ }^{1,}$ Puji Hariati Wingsih ${ }^{3}$ \\ ${ }^{1}$ Master of Physics Education, Faculty of Mathematics and Natural Sciences, Universitas Negeri Yogyakarta, \\ Indonesia \\ ${ }^{2}$ Department of Science Education, Faculty of Mathematics and Natural Sciences, Universitas Negeri Yogyakarta, \\ Indonesia \\ ${ }^{3}$ Physics Education, Faculty of Teacher Training and Education, Universitas Sarjanawiyata Tamansiswa \\ ${ }^{*}$ Corresponding author.Email: sonyyunior.2019@student.uny.ac.id; sonyyuniorerlangga@gmail.com
}

\begin{abstract}
This study aims to determine the effect of problem-based learning worksheets (PBL) through Google classrooms in improving students' critical thinking skills during the Covid-19 pandemic. The quasi-experimental method was used in this study with a sample of students of class X MIA1 and MIA2 MAN 1 Yogyakarta. In this study, the cluster random sampling technique was used, including the PBL experimental class through Google Classroom and the control class using conventional methods. Data collection techniques used multiple choices tests to obtain data on students' critical thinking skills. The data were analyzed using the t-test. The results showed a significant difference in students' critical thinking skills in the experimental class compared to the control class. Based on the research results, it is known that learning with PBL assisted by Google classroom is better and more effective than learning without assistance by Google classroom.
\end{abstract}

Keywords: Worksheet, Problem based learning, Google classroom, Critical thinking

\section{INTRODUCTION}

Education should be a solution to facing global challenges in the 21 st century, which is getting higher. Humans in this era are not only required to have cognitive intelligence but also must be able to be creative and innovative to compete with other individuals [1]. The quality of education is a solution in equipping students to face higher competition [2]. Education does not only educate students in cognitive aspects but also terms of skills. This makes students smart, honest and has good ethics. Aspects of creativity, innovation, critical thinking, problemsolving, and communication must be taught to students in 21st-century education [3].

Education is at the forefront of honing creativity, innovation, critical thinking, problem-solving, and communication skills. In daily life is that many students have difficulty understanding the subjects taught in school. Subjects that are often complained of by students are physics subjects. The content in physics is abstract and difficult for students to understand [4]. Physics is very close to our life. Impulse and momentum are some of the objects of matter in physics closely related to our daily lives. In general, physics lessons can easily hone their critical thinking skills through practical activities and problem-solving. Problems that occur can be minimized by using the appropriate learning model according to each physics learning topic [5].

21st-century learning demands competence in problem management, communication, collaboration, and critical thinking skills. The physics calculations show that understanding the principles and concepts of physics can foster critical thinking skills and have a scientific attitude [6]. Process problems, find solutions, analyze, and conduct research is critical thinking [7]. There needs to be an effort by students to have critical thinking skills to compete in this century. For example, students who are provided with critical 
thinking skills can assess whether the opinion is right or wrong [8]. So that education is currently being conceptualized to train students to have the ability to think critically in facing the challenges of everyday life.

The ability to think critically is one of the most important abilities that students must have to face this century's challenges. Thinking critically is one of the 21 st century needs that students need to have [9]. The ability to think critically is seen as the ability that is indispensable in the 21 st century to check the truth of information so that students can determine whether the information deserves to be accepted or rejected [10]. Indicators of critical thinking skills consist of interpreting, analyzing, concluding, evaluating, explaining, and self-regulation [7]. Characteristics of people who have critical thinking skills are evaluating and concluding something based on facts in making decisions [11]. Solving problems can be trained by providing problems with complex cognitive activities [12].

Critical thinking is an indicator of higher-order thinking. The term critical thinking is often equated with convergent thinking, logical thinking, and reasoning. Solving problems, making decisions, analyzing assumptions, conducting scientific research are used in mental activities and measuring critical thinking skills [13]. Critical thinking skills are essential for students. The goal is to face challenges in the future; besides that, by being equipped with critical thinking skills, students can face the problems around them [14].

Students who have critical thinking abilities tend to think openly, clearly, and every decision taken must be accompanied by reasons based on facts. They must also be open to differences of opinion. A person can see his critical thinking skills based on critical thinking indicators, namely: 1) providing simple explanations, 2) building basic skills, 3) making inferences, 4) building further explanations, 5) arranging strategies and tactics [15].

Active students have critical thinking skills. This ability is related to other abilities, such as scientific communication and student self-confidence and motivation [16]. Several studies that have been conducted show that many students have low category critical thinking skills. $32.2 \%$ of the students studied still had low critical thinking skills, and $42.8 \%$ were in the moderate category [17]. Other studies reinforce this study that the average score of students with low critical thinking skills is 65.7 [16]. This shows that the critical thinking skills of students in Indonesia are still low [18]. Therefore, we need a learning model that can be a solution to students' low critical thinking.
The problem-based learning is present as a solution to overcoming students' low level of critical thinking. The learning model consists of planning elements and procedures and steps for learning activities, including the choice of assessment methods to be carried out [19]. he learning principles of the PBL pose a problem. Giving problems is the first step in the PBL process. The problems presented are often encountered in everyday life, affecting the improvement of learning outcomes [20]. The development of this PBL is increasingly evident mainly due to the following factors: 1) There is an increasing demand for bridging the gap between theory and practice, information accessibility, and knowledge explosion; 2) The need to emphasize real-world competencies in learning; 3 ) Developments in the world of learning, psychology, and pedagogy [21].

Developing critical thinking skills and actively developing students' abilities are the main objectives of the PBL [22]. Educators in the PBL as facilitators who guide students in finding and finding the necessary solutions. Problem-based learning can help improve lifelong learning skills in an open, reflective, critical, and active learning mindset [23]. a study states that to improve critical thinking skills can use PBL [24]. The ability to think critically in physics can be improved using a problem-based learning model. The PBL can make students understand content concepts by learning and activities such as classifying, observing, measuring, predicting, concluding, etc.

The relationship between PBL and critical thinking skills, namely by using PBL, the teacher can train students' critical thinking skills because when students search for a given problem-solving process, students will use their thinking system, namely using initial knowledge related to critical thinking indicators namely providing simple explanations and building basic skills [25]. The PBL application in classroom learning can work if there are media that support it. Effective learning can be influenced by activities using learning media. Learning media that support learning in class is one of the Student Worksheets. The use of worksheets with the PBL encourages students to use critical thinking skills related to managing tactics and strategies. The strategy adopted then becomes a solution to the problems found by students [26].

The Covid-19 pandemic has resulted in tremendous changes to the world of education. All education levels are 'forced' to transform to adapt to breaking the chain of transmission of the Covid-19 virus [27]. Through the Ministry of Education and Culture (Kemendikbud), the government released an announcement regarding the prevention and handling of Covid-19 through a Ministry of Education and Culture circular [28]. One of the handlings in the world of education is learning online or online [29]. Of 
course, this has resulted in many changes in education, which have resulted in many obstacles in the learning and teaching process.

Obstacles in monitoring and short learning times can become obstacles in the learning process. Educators can use several available platforms such as google classroom, zoom, google meet, WhatsApp (WA), and others [30]. Communication and collaboration between teachers and students can be done effectively through Google Classroom [31]. Besides, learning using google classroom is more efficient and free [32]. The results of this study are supported by research that learning using google classroom has been responded positively by students and physics teachers [33].

Learning in the midst of the Covid-19 pandemic presents its own obstacles. Educators need to continue to provide content, even though learning is done online. Google Classroom can become one of the platforms that can be used in today's online learning process. Worksheet with the PBL can be submitted through the google classroom platform. Google Classroom provides a space for students to communicate online and discuss an application worksheet with PBL content and momentum. So that learning will still run well and effectively even in the midst of a pandemic with online learning.

\section{RESEARCH METHOD}

This study uses a quantitative approach. This study used a quasi-experimental research type using two classes as samples and then given different treatments. The research design used is the Posttest Only Control Group Design, which is presented in Table 1.

Table 1. Research design

\begin{tabular}{|c|c|c|}
\hline Class Type & Treatment & Posttest \\
\hline Experiment & $\mathrm{X}$ & $\mathrm{O}_{1}$ \\
\hline Control & - & $\mathrm{O}_{2}$ \\
\hline
\end{tabular}

Subject of the research were students of class $\mathrm{X}$ majoring in MIA at MAN 1 Yogyakarta. The classes used are class X MIA1 and X MIA2. The purposive sampling technique was used in this study so that class $\mathrm{X}$ MIA1 was used as the experimental class, and $\mathrm{X}$ MIA2 was used as the control class. The data technique was carried out with the value of the posttest results. Assume that both classes have initial abilities, as seen from previous exam scores. Posttest is given to see the results after being treated. The results of the posttest are also used in testing the hypothesis using the t-test statistical formula. Hypothesis testing used is the one-party test, namely the right side, with the criteria of accepting Ha if $t_{v a l u e}$ $>t_{\text {table }}$ and accepting $\mathrm{H} 0$ if $t_{\text {value }} \leq t_{\text {tablel }}$.

The t-test statistical test can be used if it meets two conditions; namely, the data must be normal through the normality test and homogeneous data. The normality test functions to determine whether the sample under study is normally distributed or not by using the chi-squared test equation. The homogeneous test is intended to determine that the two sample groups used to come from populations with the same variance. To support the results of differences in critical thinking skills, each class analyzed their level of critical thinking skills with the equations presented in equation 1 .

Level of Critical Thinking $=\frac{\text { Score }}{\text { Maximum Score }} \times 100 \%$ (1)

The calculation results from equation 1 are then interpreted into the critical thinking table of students as presented in Table 2 .

Table 2. Students' critical thinking ability level

\begin{tabular}{|c|c|}
\hline Percentage (\%) & $\begin{array}{l}\text { Critical Thinking Ability } \\
\text { Category }\end{array}$ \\
\hline $80<$ Score $\leq 100$ & Very Good \\
\hline $60<$ Score $\leq 80$ & Good \\
\hline $40<$ Score $\leq 60$ & Average \\
\hline $20<$ Score $\leq 40$ & Low \\
\hline $0 \leq$ Score $\leq 20$ & Very low \\
\hline
\end{tabular}

The gain test can be used to support and determine the increase or effectiveness of a lesson that has the same equation as shown in equation 2 .

$$
<\mathrm{g}>=\frac{\text { Average of post-test-Average of pre-test }}{100 \text {-Average of pre-test }}
$$

The calculation results from equation 2 are then interpreted into the gain value criteria table presented in Table 3.

Table 3. Gain criteria

\begin{tabular}{|c|c|}
\hline Gain & Criteria \\
\hline$g \geq 0.7$ & High \\
\hline $0.7>g>0.3$ & Average \\
\hline$g \leq 0.3$ & Low \\
\hline
\end{tabular}

\section{RESULT AND DISCUSSION}

The subjects was divided into two classes. Critical thinking skills were measured in the experimental class (learning with the PBL assisted by Google classroom) and the control class (conventional learning). The results of learning interactions with 
students in google classroom are presented in Figure $1 \mathrm{a}$ and Figure $1 \mathrm{~b}$.



Figure 1a. Learning interactions using google classroom

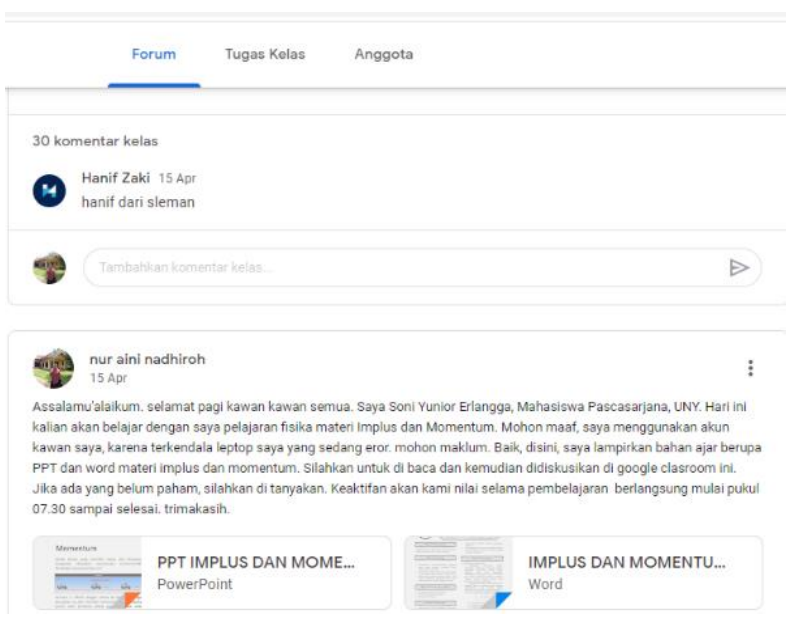

Figure 1b Learning interactions using google classroom

Table 4 provides an analysis of information related to students' critical thinking skills. The analysis results were obtained from the critical test results of the experimental class and control class students. The final products were tested using the independent t-test to see the class's critical thinking treated with the Google Classroom PBL-based treatment and the class that used conventional learning.

The results showed that the experimental class obtained an average pretest score of 64.26 of 100 , while the post-test average score was 85.06 of 100 , with an increase of 20.80 . In the control class, the average pretest score was 64.43 of 100 , while the posttest average score was 68.13 of 100 , with an increase of 3.70, as shown in Figure 2.
The results showed that the experimental class obtained an average pretest score of 64.26 , while the post-test average score was 85.06 , with an increase of 20.80 . In the control class, the average pretest score was 64.43 , while the post-test average score was 68.13 , with an increase of 3.70, as shown in Figure 2.



Figure 2. Bar chart of students' critical thinking scores

The experimental class is a class that uses learning with the PBL assisted by Google classroom, while the control class is a class that uses conventional learning. Figure 2 shows the experimental class's critical thinking skills in terms of the lowest, highest, and average scores compared to the control class.

This shows that students who experience learning with the PBL assisted by Google Classroom have better critical thinking skills. In terms of students' average critical thinking ability in the experimental class with the PBL assisted by Google Classroom, they have good critical thinking skills. In contrast, students in the control class have sufficient critical thinking skills. In detail, the comparison of students' critical thinking skills is presented accordingly. The distribution of critical thinking skills among students is presented in Table 5. Table 6 describes the statistical test results of critical thinking. Hypothesis testing provides results that there are significant differences between the experimental group and the control group.

Table 4. Descriptive analysis of critical-thinking

\begin{tabular}{|c|c|c|c|c|c|}
\hline \multirow{2}{*}{ Class Type } & \multicolumn{3}{|l|}{ The Value of Critical Thinking } & \multirow{2}{*}{ The Value of Gain } & \multirow{2}{*}{ Gain Criteria } \\
\cline { 2 - 5 } & $\mathrm{N}$ & Pre-test & Post-tests & & Average \\
\hline Experiment Class & 34 & 64.26 & 85.06 & 0.58 & Low \\
\hline Control Class & 34 & 64.43 & 68.13 & 0.11 & \\
\hline
\end{tabular}


Table 5. Distribution and critical thinking categories of students

\begin{tabular}{|l|l|l|l|l|l|l|}
\hline \multirow{2}{*}{ Class Type } & \multicolumn{4}{l|}{ Critical Thinking Ability Category } & \multirow{2}{*}{ Category average } \\
\cline { 2 - 6 } & Very low & Low & Average & Good & Very good & \\
\hline Experiment & - & - & 10 people & 17 people & 7 people & Good \\
\hline Control & - & 6 people & 12 people & 12 people & 4 people & Enough \\
\hline
\end{tabular}

Table 6. T-test results related to differences in students' critical thinking abilities

\begin{tabular}{|l|c|l|c|l|}
\hline Test & $\begin{array}{c}\text { T-test } \\
\text { Score }\end{array}$ & $\begin{array}{l}\text { Sig. } \\
\text { (2Tailed) }\end{array}$ & $\alpha$ & Conclusion \\
\hline $\begin{array}{c}\text { Experiment } \\
\text {-Control }\end{array}$ & 4.11 & 0,00 & 5 & $\mathrm{H}_{0}$ rejected \\
$\%$ & & \\
\hline
\end{tabular}

The hypothesis test results show that there is a significant difference in the critical thinking skills of students in the experimental class and the control (sig. $<0.05$ ). This means that the treatment given in the form of using the PBL assisted by Google Classroom has a different effect on students' critical thinking skills [34]. The use of google classroom makes learning run efficiently, and students are easily conditioned and monitored, making the learning atmosphere more enjoyable [32].

The use of the PBL influences the increase in students' critical thinking skills in the experimental class. PBL can provide opportunities for students to develop their critical thinking skills [14]. The PBL strategy uses problems that students often encounter in everyday life as the initial learning concept. The goal is that students can easily apply what students have obtained in the classroom into everyday life, and learning is not abstract [35]. The PBL strategy uses problems that students often encounter in everyday life as the initial learning concept. The goal is that students can easily apply what students have obtained in the classroom into everyday life, and learning is not abstract.

The experimental class researcher only directs students to the problems that have been selected then students carry out the process of solving these problems independently. When solving problems, students' thinking is optimized through the group work process through students collecting information related to problems from student management books and physics lab modules of MAN 1 Yogyakarta and searching for relevant sources available in google classroom, then process this information by discussing with the group and conducting experiments and presenting work results by showing the results of group assignments. This is in line with stating that the main purpose of the PBL is not the delivery of a large portion of knowledge to students but rather to develop critical thinking skills and problem-solving [36].

\section{CONCLUSION}

The results of the research that have been conducted show that there is a significant difference between the critical thinking skills of students in the experimental and control classes. The average value of critical thinking skills in the experimental class is higher than the control class. Therefore, it can be said that the use of worksheet with PBL assisted by Google Classroom influences the critical thinking skills of students.

\section{REFERENCES}

[1] M. Muskitta, D. Djukri, Pengaruh Model PBT terhadap Kemampuan Berpikir Kritis dan Kemampuan Berpikir Kreatif Siswa SMAN 2 Magelang, Jurnal Inovasi Pendidikan IPA 2(1) (2016) $58 . \quad$ DOI: https://doi.org/10.21831/jipi.v2i1.8809

[2] S.F. Setiyawati, H. Kuswanto, Pengembangan Buku Pedoman Guru pada Pembelajaran Fisika SMA Menggunakan Model Problem Solving Level Inkuiri, Jurnal Inovasi Pendidikan IPA 2(2) (2016) 202-212. DOI: https://doi.org/10.21831/jipi.v1i2.7509

[3] M. Firdaus, I. Wilujeng, Pengembangan LKPD Inkuiri Terbimbing untuk Meningkatkan Keterampilan Berpikir Kritis dan Hasil Belajar Peserta Didik Developing Students Worksheet on Guided Inquiry to Improve Critical Thinking Skills and Learning Outcomes of Students, Jurnal Inovasi Pendidikan IPA 4(1) (2018) 26-40. DOI: http://dx.doi.org/10.21831/jipi.v4i1.5574.

[4] S.Y. Erlangga, H. Saputro, Mini Roller Coaster (Miroco) sebagai Media untuk Menghitung Percepatan Ditinjau dari Energi Mekanik Mini Roller Coaster (Miroco) as A Media to Calculate The Terms of Acceleration of Mechanical Energy, Risal 2(2) (2018) 29-33. DOI: https://doi.org/10.35895/rf.v2i2.80

[5] T.K. Badu, M.S. Ikbal, Perbedaan Pemahaman 
Konsep Fisika Siswa melalui Model ProblemBased Learning dan Pembelajaran Interaktif, Uniqbu Journal of Exact Science 1(2) (2020) 4145. DOI: https://doi.org/10.47323/ujes.v1i2.27

[6] N. Nuraini, Critical Thinking Profile of Students of Biological Teacher Candidate as Efforts to Prepare 21st Century Generation, Jurnal Penelitian Pendidikan Biologi 1(2) (2017) 8996.

DOI: https://doi.org/10.24235/sc.educatia.v8i1.4081

[7] R. Purwati, Hobri, A. Fatahillah, Analisis Kemampuan Berpikir Kritis Siswa dalam Menyelesaikan Masalah Persamaan Kuadrat pada Pembelajaran Model Creative Problem Solving, Jurnal Matematika dan Pendidikan Matematika 7(1) (2016) 83-94. DOI: https://doi.org/10.19184/kdma.v7i1.5471

[8] P.A. Facione, Critical Thinking: What It Is and Why It Counts, Insight Assess., pp. 1-28, 2011, Accessed on: Oct. 2020, [Online]. Available: https://www.researchgate.net/profile/PeterFacione/publication/251303244

[9] H. Fitriani, M. Asy’ari, S. Zubaidah, S. Mahanal, Exploring The Prospective Teachers' Critical Thinking and Critical Analysis Skills, Jurnal Pendidikan IPA Indonesia 8(3) (2019) 379-390. DOI: https://doi.org/10.15294/jpii.v8i3.19434

[10] K.M. Rahmawati, S.H.B. Prastowo, S. Bektiarso, Pengembangan Bahan Ajar Fisika Berbasis Scientific Approach untuk Meningkatkan Kemampuan Berpikir Kritis Siswa pada Materi Medan Magnet di SMA, Jurnal Pembelajaran Fisika 8(2) (2019) 80-86. DOI: https://doi.org/10.19184/jpf.v8i2.11663

[11] R.H. Ennis, Critical Thinking Across The Curriculum: A Vision, Topoi 37(1) (2018) 165184. DOI: https://doi.org/10.1007/s11245-0169401-4

[12] I.W. Widana, Higher Order Thinking Skills Assessment towards Critical Thinking on Mathematics Lesson, International Journal Social Science Humanity 2(1) (2018) 24-32. DOI: https://doi.org/10.29332/ijssh.v2n1.74

[13] S. Mahanal, S. Zubaidah, I.D. Sumiati, T.M. Sari, N. Ismirawati, RICOSRE: A learning Model To Develop Critical Thinking Skills for Students with Different Academic Abilities, International Journal Instruction 12(2) (2019) 417-434. DOI: . https://doi.org/10.29333/iji.2019.12227a

[14] C.R. Huber, N.R. Kuncel, Does College Teach Critical Thinking? A Meta-Analysis, Review Education Research 86(2) (2016) 431-468. DOI: https://doi.org/10.3102/0034654315605917

[15] M. Duran, I. Dökme, The Effect Of The InquiryBased Learning Approach on Student's CriticalThinking Skills, Eurasia Journal Mathematics Science Technology Education 12(12) (2016) 2887-2908.

DOI: https://doi.org/10.12973/eurasia.2016.02311a

[16] W. Hu et al., Effects of A Critical Thinking Skills Program on the Learning Motivation of Primary School Students, Roeper Review 38(2) (2016) $70-83$

DOI: https://doi.org/10.1080/02783193.2016.1150374

[17] Matsun, W. Sunarno, M. Masykuri, Penggunaan Laboratorium Riil dan Virtuil pada Pembelajaran Fisika Dengan Model Inkuiri Terbimbing Ditinjau dari Kemampuan Matematis dan Keterampilan Berpikir Kritis, Jurnal Pendidikan Fisika 4(2) (2016) 137-152. DOI: http://dx.doi.org/10.24127/jpf.v4i2.541

[18] E. Szenes, N. Tilakaratna, K. Maton, The Knowladge Practices of Critical Thinking, Palgrave Macmillan, (2015) 573-591, DOI: https://doi.org/10.1057/9781137378057.0043

[19] A.S. Argaw, B.B. Haile, B.T. Ayalew, S.G. Kuma, The Effect of Problem Based Learning (PBL) Instruction on Students' Motivation and Problem Solving Skills of Physics, Journal Mathematics Science Technology Education 13(3) (2017) 857-871. DOI: https://doi.org/10.12973/eurasia.2017.00647a

[20] R. Phungsuk, C. Viriyavejakul, T. Ratanaolarn, Development of A Problem-Based Learning Model Via A Virtual Learning Environment, Kasetsart Journal of Social Science 38(3) (2017) 297-306.

DOI: https://doi.org/10.1016/j.kjss.2017.01.001

[21] A. Burgess, C. Roberts, T. Ayton, C. Mellis, Implementation of Modified Team-Based Learning Within A Problem Based Learning Medical Curriculum: A focus group study, BMC Medica Education 18(1) (2018) 1-7. DOI: https://doi.org/10.1186/s12909-018-1172-8

[22] M.A. Ghufron, S. Ermawati, The strengths and Weaknesses of Cooperative Learning and Problem-Based Learning In Efl Writing Class: Teachers and Students' Perspectives, International Journal Instruction 11(4) (2018) 657-672.

DOI:

https://doi.org/10.12973/iji.2018.11441a

[23] R. Ramadhani, R. Umam, A. Abdurrahman, M. Syazali, The Effect of Flipped-Problem Based Learning Model Integrated with Lms-Google 
Classroom for Senior High School Students, Journal for The Education of Gifted Young Scientists 7(2) (2019) 137-158. DOI: https://doi.org/10.17478/jegys.548350

[24] N.N.P.N.N. Utami, I.W. Santyasa, I. Suswandi, The Influence of Blended Learning Model Based on Problems of Physical Learning Achievements by Students of Class X Science in SMA 6 Denpasar Academic Year 2017/2018, Indonesian Review Physics 1(1) (2018) 1-6. DOI: https://doi.org/10.12928/irip.v1i1.253

[25] H.H. Herzon, Budijanto, D.H. Utomo, Pengaruh Problem-Based Learning (PBL) terhadap Keterampilan Berpikir Kritis, Jurnal Pendidikan, Teori, Penelitian, dan Pengembangan 3(1) (2018) 42-46. DOI: http://dx.doi.org/10.17977/jptpp.v3i1.10446

[26] S. Astuti, M. Danial, M. Anwar, Pengembangan LKPD Berbasis PBL (Problem Based Learning) untuk Meningkatkan Keterampilan Berpikir Kritis Peserta Didik pada Materi Kesetimbangan Kimia, Chemistry Education Review 1(2) (2018) 24-26.

DOI: https://doi.org/10.26858/cer.v0i1.5614

[27] I.M.A. Winaya, Pengembangan Nilai-Nilai Karakter Anak Pada Pembelajaran Jarak Jauh di Masa Pandemi Covid-19 dengan Berbantu Lembar Keja Siswa Berbasis Proyek, Jurnal Pendidikan Kewarganegaraan Undiksha 8(3) (2020) 117-123. DOI: http://dx.doi.org/10.23887/jpku.v8i3.28612

[28] I.P.Y. Purandina, I.M.A. Winaya, Pendidikan Karakter di Lingkungan Keluarga Selama Pembelajaran Jarak Jauh pada Masa Pandemi COVID-19, Cetta Jurnal Ilmu Pendidikan 3(2) (2020) 270-290. DOI: https://doi.org/10.37329/cetta.v3i2.454

[29] Firman and S.R. Rahman, Pembelajaran Online di Tengah Pandemi Covid-19, Indonesian Journal Education Science 2(2) (2020) 81-89. DOI: https://doi.org/10.31605/ijes.v2i2.659

[30] L.D. Herliandry, Nurhasanah, M.E. Suban, K.
Heru, Pandemic Learning during The Covid-19, Jurnal Teknologi Pendidikan 22(1) (2020) 6570 . DOI:

https://doi.org/10.21009/jtp.v22i1.15286

[31] S. Iftakhar, Google Classroom: What Works and How?, Journal Education Social Science, 2016, vol. 3, pp. 12-18.

[32] O.V Bondarenko, S.V Mantulenko, Google classroom as a tool of support of blended learning for geography students, CEUR Workshop Proceedings, ARxIV, 2018, pp. 182191, DOI: https://doi.org/arXiv:1902.00775

[33] M.H. Hariadi, I. Wilujeng, H. Kuswanto, S. Sundari, Inquiry Training Learning Model Assisted by Google Classroom to Improve Creative Thinking Skills of Senior High School Students, Jurnal Pendidikan Fisika 8(2) (2019) 198-207. DOI: https://doi.org/10.23887/jpiundiksha.v8i2.17339

[34] M.N. Solikh, D. Sulisworo, G. Maruto, Pengaruh Model Pembelajaran Blended Learning Berbantuan Google Classroom Terhadap Kemampuan Berpikir Kritis Ditinjau dari Self Esteem dan Kecerdasan Intelektual, Jurnal Materi dan Pembelajaran Fisika 8(2) (2018) 27 32.

DOI: https://doi.org/10.20961/jmpf.v8i2.28434.

[35] R. Diani, A.S.A. Ifana, Perbandingan Model Pembelajaran Problem Based Learning dan Inkuiri Terbimbing Terhadap Kemampuan Berpikir Kritis Peserta Didik, Jurnal Penelitian Pembelajaran Fisika 7(2) (2016) 147-155, 2016. DOI: https://doi.org/10.26877/jp2f.v7i2.1310

[36] I. Al-fikry, M. Syukri, Pengaruh Model Problem Based Learning Terhadap Kemampuan Berpikir Kritis Peserta Didik pada Materi Kalor, Indonesian, Journal Science Education 6(1) (2018) 17-23. DOI: https://doi.org/10.24815/jpsi.v6i1.10776 